\title{
Leadership Types and Digital Leadership in Higher Education: Behavioural Data Analysis from University of Patras in Greece
}

\author{
Hera Antonopoulou, Constantinos Halkiopoulos, \\ Olympia Barlou and Grigorios N. Beligiannis \\ University of Patras \\ Patras, Greece
}

\begin{abstract}
The effective leadership of digital transformation in higher education has become an emerging issue that is needed to also integrate the board of directors in University departments. The main purpose of the study is to investigate the leading skills of heads of university departments analyzing their point of view in the digital leadership, to analyze the leadership types that they adopt and the associations with leadership outcome and also to describe profoundly the views of participants as far as the basic components of leadership types such as transformational and transactional. For the implementation of the present study, 28 heads of departments from University of Patras participated replying the Multi-factor Leadership Questionnaire (MLQ) and data were collected and then analyzed using SPSS statistical software. The findings of the study among others, indicate that the leadership outcome has a strong positive correlation with transformational leadership and a large negative correlation with passive - to avoid leadership, it was confirmed that the higher degree of transformational leadership implies greater efficiency and satisfaction for workers, and the high degree of transformational leadership co-exists with the great degree of implementation of digital leadership.
\end{abstract}

Keywords: digital leadership; higher education; behavioral data analysis; transformational leadership; outcome leadership

\section{Introduction}

\subsection{Literature review of leadership}

Leadership and its exercise have run and occupied every organized human society. But the science of management is systematic and organized and made its appearance in the early twentieth century, focusing primarily on area of Business Administration. Gradually this scientific space it was embedded, grafted and developed, taking advantage of the synergy and other sciences such as 
Psychology and Sociology, creating several 'branches', one of which is the field of Education Leadership-Management.

Many theorists (Cuban, 1988), define that the term of leadership means the influence on the actions of others when trying to achieve desired goals. The role of leadership is to achieve innovation in the way the organization operates, the transformation of existing structures and processes taking place within it, as well as the effort to change the working culture and behavior of its employees (Fullan, 2002). On the contrary, management in an organization looks forward to the implementation and maintenance of existing structures and their optimal operation within the frameworks specified. Another theorist (Bennis, 1990), quite rightly points out that "the manager does things right while the leader does the right things ". In addition, it is mentioned in philosophy terms that "Leadership is like beauty: it's hard to define, but you understand it immediately when you meet it".

\subsection{Types of leadership (transactional vs transformational)}

During the decade of '70 and specifically in 1978, Burns theory discriminates leadership in two principal types: transactional and transformational leadership. More specifically, Burns (1978) identified the transactional leader as one who recognizes the needs of his subordinates and tries to continue to fulfill them, provided that their performance is worthwhile for rewarding.

The transactional leader seeks to maintain the stability of the organization, constantly striving to achieve set goals, despite promoting change (Bryant, 2003; Lussier \& Achua, 2004). The means used to implement them is to use them fees and penalties, mainly in the form of financial exchanges (Barnett, 2003; Gellis, 2001). Bass \& Bass (2008) consider that these rewards can be either psychological (e.g. positive feedback, praise and applause), or tangible (e.g. promotion, salary increase / bonus).

Furthermore, transactional leadership includes four dimensions: Contingent reward leadership, active management by exception, passive management by exception and avoidant (laissez faire) leadership (Bass, 1985).

a. Contingent reward leadership: Leader provides various types of rewards to its affiliates, in order to fulfill their contractual obligations. Partners offer "in return" their good services and their commitment to achieving the determined goals of the organization. According to Bass (1997), business leaders clarify expectations, exchange for promises and pay for support in their work, they reach mutually acceptable agreements, they negotiate resources, they exchange help with effort and provide applause in return for the successful attempt. From this perspective, this is a constructive one transaction (Bass \& Bass, 2008).

b. Active Management by exception: The leader who uses that particular style of administration, monitor the performance of its subordinates and take corrective action when this deviates from expectations (Bass \& Bass, 2008). 
c. Passive Management by exception: The difference of this particular style of administration from the previous one, it is the time for the leader to solve the problems (Howell \& Avolio, 1993). In Active Exception Management the leader acts before problem become serious, while in Passive Exception Management, action on the part of the leader manifests itself when it has already emerged (Judge \& Piccolo, 2004).

d. Avoidant leadership: Following this particular style of administration, these leaders simply avoid leadership responsibilities. It is considered the most ineffective form into the extent that some may not even regard it as a form of transaction leadership (Judge \& Piccolo, 2004).

The transactional leadership model often leads to no desirable results because employees tend to be lacking interest in doing their work which is beyond them narrow limits on their employment contract, or the formal limits of their employment

(Bryant, 2003). Although, contingent reward leadership can have positive impact on the performance of employees, active, passive and avoidant leadership tend to have a negative impact the above indicators, especially, when the leader passively expects problems to arise (Waldman, Atwater \& Bass, 1992).

The transformational leader is the one who together with his associates is involved to outrun the personal interests, motivating them to go beyond the benefit of the organization. Transformational leaders focus on higher needs, such as appreciation, the recognition and self - actualization as defined by classification of Maslow's human needs (1943). Inspire their partners through the interest they show for them, their mental stamina, their tendency to take risks and their constant commitment to achieving the goals. They don't complain either believe in continuous improvement. They try to design and implement significant changes in goals, strategy, structures and activities of the organization while trying to satisfy and the needs of their partners (Balvant, 2016).

Additionally, they try to make use of them their previous successes, building a climate of trust and confidence in the organization. Transformational Leadership is characterized as the most active and effective form of leadership (Bass \& Avolio, 1994), as it provides fans a sense of purpose and mission, improves self-awareness and suggests a vision (Lowe et al., 1996). Also, the Transformational Leader's behavior is positively correlated with his effectiveness and increased team performance (Judge \& Piccolo, 2004; Lowe et al., 1996). Research still shows that partners Transformational leaders tend to feel more satisfied and more productive than transactional partners (Carless et al, 2000). Also, according to Bass (1985), the leadership of the great historical figures over time, it was transformational, not transactional.

Burns (1978) considered the concepts of transactional and transformational leadership as the opposite ends of the same dimension, the leader or the transactional, either as a transformer. In contrast, Bass and his colleagues (Avolio, Bass \& Jung, 1999; Bass, 1985) regarded the two above forms of leadership as complementary to each other, and the leader as capable of displaying evidence 
and behaviors from both of these forms of leadership (Bass, 1998). These researchers promote a unified theory according to which Transformational leadership is seen as an extension of transactional as the relationship between leader and subordinate evolves (Howell \& Avolio, 1992; Howell \& Hall-Merenda, 1999). The key to this transformation is the positive and constructive feedback from the leader. Acceptance by the fact that his fans' efforts are appreciated, encourages them the latter to seek further investment and deepening in their relationships with the leader. This, in turn, results in a gradual evolution between them of a transactional relationship, in a relationship governed by trust and honesty, two crucial components of a close partnership (Northouse, 2016).

\subsection{Leadership outcome}

The leadership style in an organization (transformational/transactional) is related with the success of the team as a whole. One of the most important tools measuring success is the MLQ (Multifactor Leadership Questionnaire). The three elements that make up the outcome of leadership are the following: a) The degree of motivation according to which rater consider that their leader is motivating them (Extra effort), b) The effectiveness with which they perceive their leader to interact at the various organizational levels (Effectiveness), c) the degree of satisfaction they derive from the leader's working methods (Satisfaction with the Leadership). (Avolio \& Bass, 2004). Extra effort motivates others to do more of themselves they thought they would and incites others to succeed and increases also the desire for others to strive harder. (Avolio \& Bass, 2004). The effectiveness has to do with the leader and with the questions that poses to himself for feedback about degree of representation of his team in higher organizational levels, the level of satisfaction of work needs and also about the leading of an effective team. The satisfaction with the leadership associates with the use of appropriate methods of leading and with the collaboration with others (Avolio \& Bass, 2004).

In conclusion, research based on Multifactorial Multi-factor Leadership Questionnaire (Avolio \& Bass, 2004), have shown that employees who give their leaders a high rating on the transformation components, they rate them at the same time as extremely effective, in contrast to those who score highly on the transactional components and are considered less effective (Bass, 1985; Avolio \& Bass, 1988).

\subsection{Literature review of digital leadership}

According to the latest empirical data of Eurobarometer survey, digital technology has been proven as being beneficial in economy because has offered privileges in people's everyday lives and businesses. In addition, digital technologies, in the last years, have modified information, value and management and incite organizations, except for businesses but also education settings to transform their work processes and adopt radical and innovative changes in their structure and function (Cortellazzo, Bruni \& Zampieri, 2019). Digital leadership in education refers to the integration of a portfolio of technologies, tools and instruments like: Internet of Things (IoT), e-platforms (webinars) social media, Artificial Intelligence, Big Data, Machine Learning. Higher education is without doubt a type of organization that can be promoted by digitalization not only with the integration of new technologies but also by the transformation of traditional 
workplaces into digital workplaces. Under the previous perspective of digitalization, job requirements need to be profoundly transformed and as a result leaders ought to be highly aware of all demanding challenges from investing in upskilled employees and deeply know how to motivate and inspire them till the knowledge to break conventional leadership from task-oriented to projectoriented leading. Digital leadership can be beneficial for educational settings and it is a crucial parameter that is necessary to be promoted among educational leaders in higher education (Antonopoulou, et al., 2019) and in particular among heads of university departments which is the main purpose of the present study.

\subsection{Research Questions}

Research cases can be summarized as follows:

- Which leadership style prevails?

- Are the style and leadership outcome differentiated according to the leader's gender and years of service in administrative position?

- Does the leadership style relate to the knowledge and application of specific e-skills?

- Does the direction of the School (Theoretical - Applied - Other) relate to the presence of digital leaders?

\subsection{Research Scope}

If Members of the Senate in Higher Education who have the Digital Leader (eSkills) profile, follow a specific type of Leadership.

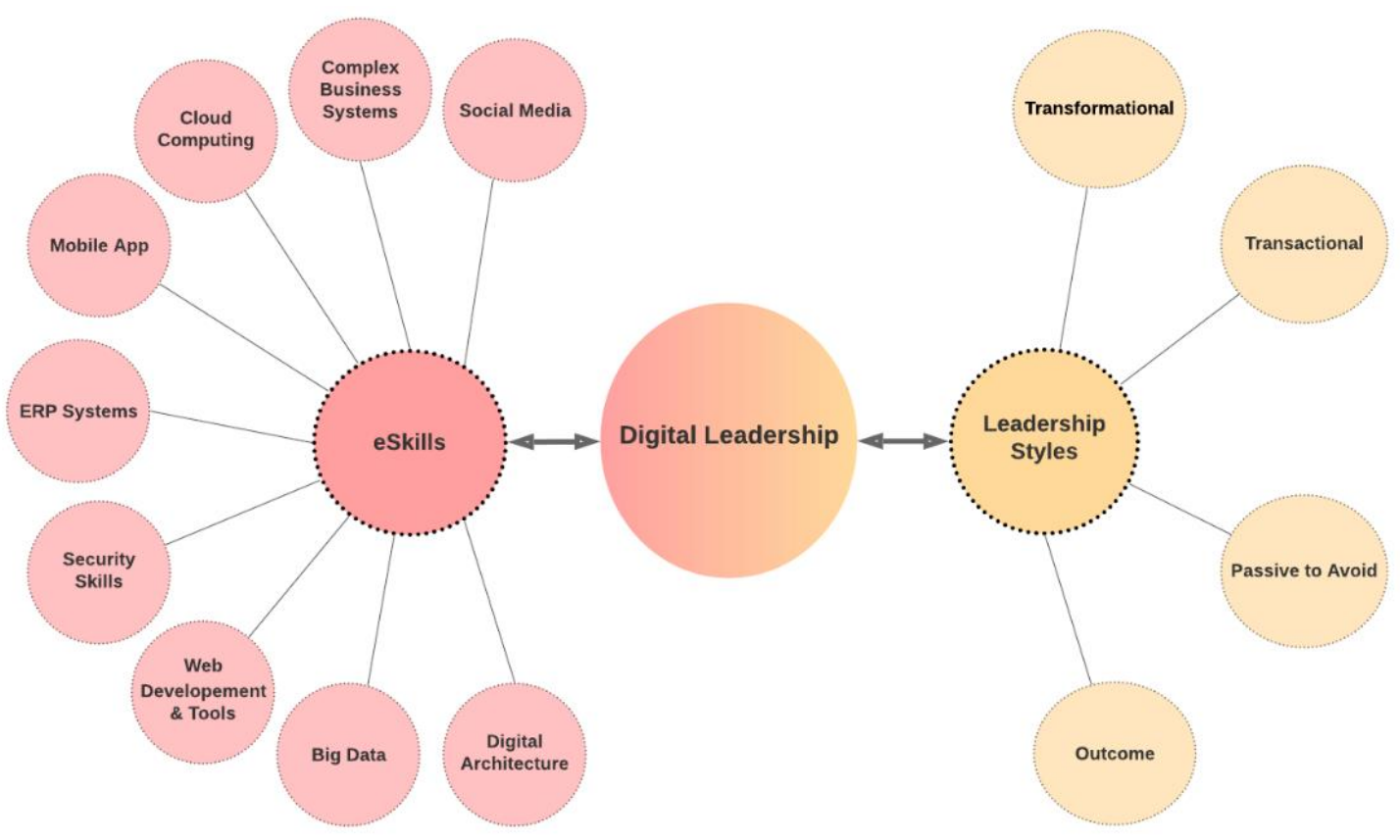

Figure 1: Conceptual Model of the Research Project 


\section{Methods}

\subsection{Data Collection}

The method to be followed for collecting data is to fill in an anonymous questionnaire. This is a method that is considered to be the most appropriate for collecting data about opinions, attitudes, beliefs and values. The data to be collected will be quantified, statistically analyzed and deduced from the analysis of conclusions, which are generalizable in larger population groups. The anonymity of responses may contribute to the honesty of the subjects' responses (Cohen, et al., 2008, Vambuka, 2007).

\subsection{Sample}

A questionnaire with closed-ended questions, consisting of three parts, will be used to collect the survey data. The first part contains questions related to the demographic data of the sample, such as gender, age, years of service in a university position, category of subject, class (theoretical, applied, etc.).

The performance of the questionnaire to members of the Senate $(\mathrm{N}=28)$ will be implemented through a unique completion link through Google's Google Form application. The information to be collected will be coded and analyzed using a statistical program, namely the SPSS program. The comparison of demographicdescriptive data will be done either by spreading analysis or by Pearson's $\mathrm{X}^{2}$ analysis. The correlation between the variables will be done with regression analysis.

\subsection{Data Collection Tool}

As a measure of the leadership style of the a fore mentioned executives, the Multifactor Leadership Questionnaire was used Leadership Questionnaire (MLQ) and more specifically the MLQ Form (Form 5X Short) developed by Bass and Avolio (2004). That particular one formula, MLQ (5X-Short), according to Avolio \& Bass (2004), is structured from 45 questions, of which 36 explore the 9 leadership components included in Full Range Leadership (FRL) - (4 questions / leaderboard), namely: i. Transformational (5 Leadership Ingredients) ii. Transactional (Contingent Reward \& Management by Exception-Active) - (2 Lead Components) iii. Passive-Avoiding Leadership (Management by Exception Passive \& Avoidant/Laissez-Faire Leadership) - (2 Leadership Ingredients) Also, the remaining 9 questions of this scale explore the leadership outcomes:

a) Extra effort - (3 questions)

b) Effectiveness - (4 questions)

c) Satisfaction with the leadership - (2 questions)

The measurement and evaluation of the above nine leading factors, such as and the outcome of leadership is made by appropriately matching - utilizing 45 total questions that make up the MLQ (5X-Short). Respondents were asked to rate the extent to which they exhibited specific behaviors, on a Likert type scale from 1 (Not at all) to 5 (Almost always) by answering 45 questions. Digital leadership was similarly measured, using 5 related questions. For each respondent, the average of the answers for each leadership style is calculated and an individual 
average score can range from 1 - 5 . The higher the score, the more the respondent exercises that particular leadership style.

ICT trends are expected to affect the demand for more specialized digital skills and skills related to Digital Leadership over the next decade. The key question now is whether technological advances impact the digital skills of a Digital Leader (Shafer, 2016). The selection of the most important trends was based on the following criteria (Lighton, 2018; Jenkins \& Andenoro, 2016; Bolden et al., 2008): a) Mobility, b) Cloud Computing, c) Big Data Analysis, d) Social Media Technologies, e) Internet of Things, f) Customer Experience, g) IT Security

\subsection{Measures and Data Analysis}

The responses of the survey participants were appropriately coded appropriately and entered into a database where they were processed and analyzed using specifically SPSS v.22. Statistical questionnaires were classified into categorical and ordinal variables. Different descriptive and inductive statistical methods of statistical analysis were applied to each category of variables. Specifically, descriptive methods were applied to the categorical variables (demographic characteristics, digital skills), such as Frequency - Percentage Tables, Percentage Charts and Pie Charts, and more inductive methods such as $\mathrm{X}^{2}$ test to investigate possible relationship between two categorical variables. Descriptive methods such as minimum value, maximum value, mean value, standard deviation, mean bars and in addition inductive methods were used for non-parametric variables (leadership style, leadership outcome, number of digital skills). comparison of the means of two independent samples), Kruskal-Wallis (to compare the means of three or more independent samples) and the Wilcoxon Signed Ranks Test (to compare the means of two related samples).

The possible correlation between the various ordinal variables was investigated through the Pearson linear correlation coefficient. Also, the possible dependence between the various layout variables was investigated through simple linear regression. Reliability of the different scales of questions regarding leadership types and leadership outcome was measured with the Cronbach's alpha reliability index. Indicator values above 0.7 (or above 0.6 according to various researchers) show satisfactory reliability. For all hypothesis tests of statistical tests, correlations and linear regressions, a significance level of $\alpha=0.05$ was used.

\section{Results}

The majority of the participants are males $(75.0 \%)$, while $1 / 4$ are females $(25.0 \%)$. As members of the Senate, $42.9 \%$ of respondents belong to the age group of $60+$ years and $39.3 \%$ are $51-60$ years. However, there is also a $17.9 \%$ share in the $41-50$ age group. Sample members have many years of service in higher education, with $75.0 \%$ serving more than 20 years. Also, 53.6\% have been in management positions for more than 9 years. Finally, most participants came from the Natural and Applied Sciences Direction (67.9\%) and 28.6\% came from the Humanities and Social Sciences Direction. 
Table 1: Demographic characteristics $(\mathrm{N}=\mathbf{2 8})$

\begin{tabular}{cccc}
\hline & & $\begin{array}{c}\text { Frequency } \\
(\mathbf{N})\end{array}$ & $\begin{array}{c}\text { Percentage } \\
(\%)\end{array}$ \\
\hline SEX & Male & 21 & 75,0 \\
& Female & 7 & 25,0 \\
\hline & $\mathbf{4 1 - 5 0}$ & 5 & 17,9 \\
AGE & $\mathbf{5 1 - 6 0}$ & 11 & 39,3 \\
& $\mathbf{5 0}$ & 12 & 42,9 \\
\hline YEARS OF & $\mathbf{6 - 1 0}$ & 1 & 3,6 \\
SERVICE IN & $\mathbf{1 1 - 2 0}$ & 6 & 21,4 \\
HIGHER & $>\mathbf{2 0}$ & 21 & 75,0 \\
EDUCATION & $\mathbf{0 - 3}$ & 6 & 21,4 \\
YEARS OF & $\mathbf{4 - 6}$ & 4 & 14,3 \\
SERVICE IN & $\mathbf{7 - 9}$ & 3 & 10,7 \\
ADMINISTRATIVE & $\mathbf{> 9}$ & 15 & 53,6 \\
POSITION & Humanities and Social Sciences Direction & 8 & 28,6 \\
\hline & Natural and Applied Sciences Direction & 19 & 67,9 \\
SUBJECT FIELD & Other & 1 & 3,6 \\
\hline
\end{tabular}
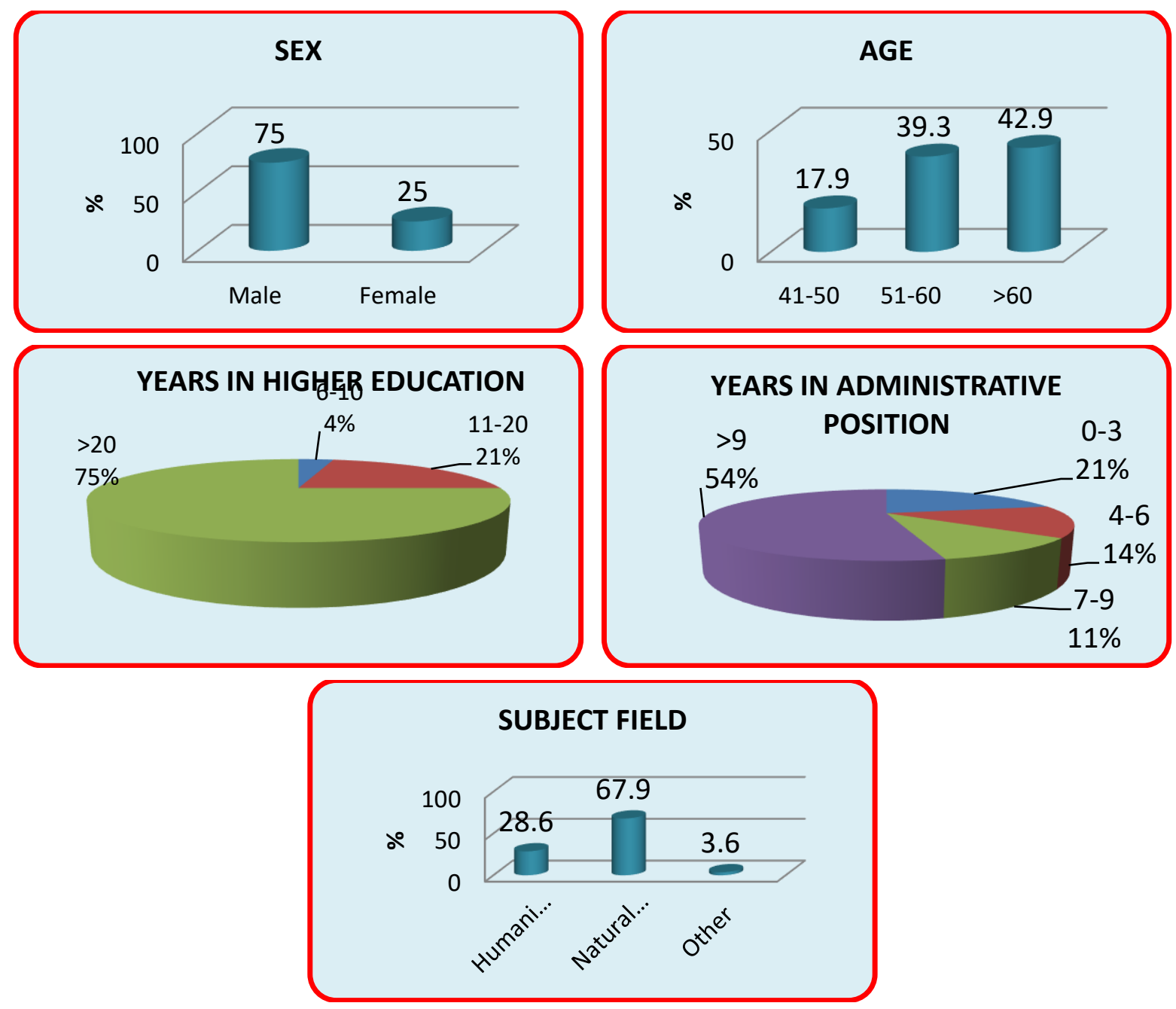

Figure 2: Demographic Characteristics $(\mathrm{N}=28)$ 


\subsection{Leadership Types Overview}

Reliability of all scales is satisfactory as Cronbach's alpha ranges from 0.530 (in the case of passive leadership) to 0.849 (in the case of leadership outcome). Particularly in the case of digital leadership, Cronbach's alpha stands at 0.819 . This fact allows to consider that the 5 questions that measure this particular leadership style belong to the same conceptual unit and can be represented by a new variable as the average of these 5 questions.

Table 2: Examined variables

\begin{tabular}{lcccccc}
\hline & N & Min & Max & Mean & SD & $\begin{array}{c}\text { Cronbach's } \\
\text { Alpha }\end{array}$ \\
\hline Transformational leadership & 28 & 3,45 & 4,85 & 4,05 & 0,329 & 0,697 \\
\hline Transactional leadership & 28 & 3,14 & 5,00 & 3,89 & 0,521 & $0,712^{*}$ \\
\hline Passive to avoid leadership & 28 & 1,00 & 3,20 & 1,60 & 0,563 & $0,530^{* *}$ \\
\hline Outcome leadership & 28 & 3,11 & 5,00 & 4,01 & 0,522 & 0,849 \\
\hline Digital leadership & 28 & 2,00 & 5,00 & 3,92 & 0,789 & 0,819 \\
\hline
\end{tabular}

* Excluded question 1 which was found to be negatively correlated with the other questions for this style Leadership

** Excluded were questions 3, 28 and 33 that were not related to the other questions for this particular leadership style

Respondents (table 3) have a high degree of transformational leadership (Mean 4.05) and Transactional leadership (Mean 3.89) with a slightly lower frequency. The difference in the degree of performance of these two (2) leadership types is not statistically significant $(p>0.05)$. On the contrary, participants avoid practicing passive - avoiding leadership (Mean 1.60). In fact, this style is practiced to a lesser degree than transformational and transactional leadership $(\mathrm{p}<0.05)$.

Table 3: Differences between leadership types

\begin{tabular}{|c|c|c|c|c|}
\hline & MEAN & SD & Test & $\begin{array}{c}\text { P- } \\
\text { value }\end{array}$ \\
\hline Transformational leadership & 4,05 & 0,329 & \multirow{2}{*}{$\begin{array}{c}\text { Wilkoxon } \\
\text { Signed Ranks } \\
\text { Test }\end{array}$} & \multirow{2}{*}{0,054} \\
\hline Transactional leadership & 3,89 & 0,521 & & \\
\hline Transformational leadership & 4,05 & 0,329 & \multirow{2}{*}{$\begin{array}{c}\text { Wilkoxon } \\
\text { Signed Ranks } \\
\text { Test }\end{array}$} & \multirow{2}{*}{$0,000^{* *}$} \\
\hline Passive to avoid leadership & 1,60 & 0,563 & & \\
\hline Transactional leadership & 3,89 & 0,521 & \multirow{2}{*}{$\begin{array}{c}\text { Wilkoxon } \\
\text { Signed Ranks } \\
\text { Test }\end{array}$} & \multirow{2}{*}{$0,000 * *$} \\
\hline Passive to avoid leadership & 1,60 & 0,563 & & \\
\hline
\end{tabular}

Mean 4.01 in leadership outcome shows great effectiveness and satisfaction with the leadership style followed, while respondents appear to be heavily practicing digital leadership (Mean 3.92). 


\subsection{Demographic based leadership types}

In order to determine if demographic characteristics influence statistically significant leadership style, non-parametric Mann-Whitney and Kruskal-Wallis tests were performed (table 4).

Table 4: Leadership style per Sex

\begin{tabular}{|c|c|c|c|c|c|}
\hline Leadership style & SEX & MEAN & SD & Test & P-value \\
\hline \multirow{2}{*}{$\begin{array}{c}\text { Transformational } \\
\text { leadership }\end{array}$} & Male & 4,11 & 0,344 & \multirow{2}{*}{ Mann-Whitney } & \multirow{2}{*}{$0,031^{*}$} \\
\hline & Female & 3,86 & 0,195 & & \\
\hline \multirow{2}{*}{$\begin{array}{l}\text { Transactional } \\
\text { leadership }\end{array}$} & Male & 4,04 & 0,468 & \multirow{2}{*}{ Mann-Whitney } & \multirow{2}{*}{$0,004^{* *}$} \\
\hline & Female & 3,43 & 0,404 & & \\
\hline \multirow{2}{*}{$\begin{array}{l}\text { Passive to avoid } \\
\text { leadership }\end{array}$} & Male & 1,61 & 0,611 & \multirow{2}{*}{ Mann-Whitney } & \multirow{2}{*}{0,756} \\
\hline & Female & 1,57 & 0,423 & & \\
\hline \multirow{2}{*}{ Outcome leadership } & Male & 4,15 & 0,522 & \multirow{2}{*}{ Mann-Whitney } & \multirow{2}{*}{$0,004^{* *}$} \\
\hline & Female & 3,60 & 0,247 & & \\
\hline \multirow{2}{*}{ Digital leadership } & Male & 4,17 & 0,643 & \multirow{2}{*}{ Mann-Whitney } & \multirow{2}{*}{$0,007^{* *}$} \\
\hline & Female & 3,17 & 0,743 & & \\
\hline
\end{tabular}

Initially, gender influences the degree to which each member of the senate involved in the research develops each leadership style. Male respondents reported significantly higher transformational leadership $(p<0.05)$, transactional leadership $(p<0.05)$ and digital leadership $(p<0.05)$ than women. Also, male participants were statistically significantly more satisfied with the outcome of leadership followed $(\mathrm{p}<0.05)$.

Table 5: Leadership types per Age

\begin{tabular}{|c|c|c|c|c|c|}
\hline Leadership types & AGE & MEAN & SD & Test & P-value \\
\hline \multirow{3}{*}{$\begin{array}{c}\text { Transformational } \\
\text { leadership }\end{array}$} & $41-50$ & 3,81 & 0,222 & \multirow{3}{*}{ Kruskal-Wallis } & \multirow{3}{*}{0,129} \\
\hline & $51-60$ & 4,06 & 0,218 & & \\
\hline & $>60$ & 4,14 & 0,411 & & \\
\hline \multirow{3}{*}{$\begin{array}{l}\text { Transactional } \\
\text { leadership }\end{array}$} & $41-50$ & 3,60 & 0,341 & \multirow{3}{*}{ Kruskal-Wallis } & \multirow{3}{*}{0,220} \\
\hline & $51-60$ & 3,79 & 0,488 & & \\
\hline & $>60$ & 4,10 & 0,559 & & \\
\hline \multirow{3}{*}{$\begin{array}{l}\text { Passive to avoid } \\
\text { leadership }\end{array}$} & $41-50$ & 1,84 & 0,654 & \multirow{3}{*}{ Kruskal-Wallis } & \multirow{3}{*}{0,300} \\
\hline & $51-60$ & 1,49 & 0,677 & & \\
\hline & $>60$ & 1,60 & 0,409 & & \\
\hline
\end{tabular}




\begin{tabular}{|c|c|c|c|c|c|}
\hline \multirow{3}{*}{ Outcome leadership } & $41-50$ & 3,93 & 0,186 & \multirow{3}{*}{ Kruskal-Wallis } & \multirow{3}{*}{0,784} \\
\hline & $51-60$ & 3,88 & 0,383 & & \\
\hline & $>60$ & 4,17 & 0,690 & & \\
\hline \multirow{3}{*}{ Digital leadership } & $41-50$ & 4,16 & 1,23 & \multirow{3}{*}{ Kruskal-Wallis } & \multirow{3}{*}{0,447} \\
\hline & $51-60$ & 3,84 & 0,612 & & \\
\hline & $>60$ & 3,90 & 0,779 & & \\
\hline
\end{tabular}

Table 6: Leadership types per Years of Service in Higher Education

\begin{tabular}{|c|c|c|c|c|c|}
\hline Leadership types & $\begin{array}{l}\text { Years of } \\
\text { Service }\end{array}$ & MEAN & SD & Test & P-value \\
\hline \multirow{2}{*}{$\begin{array}{c}\text { Transformational } \\
\text { leadership }\end{array}$} & $<20$ & 3,89 & 0,245 & \multirow{2}{*}{ Mann-Whitney } & \multirow{2}{*}{0,113} \\
\hline & $>20$ & 4,11 & 0,339 & & \\
\hline \multirow{2}{*}{$\begin{array}{l}\text { Transactional } \\
\text { leadership }\end{array}$} & $<20$ & 3,76 & 0,427 & \multirow{2}{*}{ Mann-Whitney } & \multirow{2}{*}{0,640} \\
\hline & $>20$ & 3,93 & 0,553 & & \\
\hline \multirow{2}{*}{$\begin{array}{l}\text { Passive to avoid } \\
\text { leadership }\end{array}$} & $<20$ & 1,66 & 0,629 & \multirow{2}{*}{ Mann-Whitney } & \multirow{2}{*}{0,917} \\
\hline & $>20$ & 1,58 & 0,555 & & \\
\hline \multirow{2}{*}{ Outcome leadership } & $<20$ & 3,87 & 0,244 & \multirow{2}{*}{ Mann-Whitney } & \multirow{2}{*}{0,640} \\
\hline & $>20$ & 4,06 & 0,584 & & \\
\hline \multirow{2}{*}{ Digital leadership } & $<20$ & 4,11 & 1,006 & \multirow{2}{*}{ Mann-Whitney } & \multirow{2}{*}{0,249} \\
\hline & $>20$ & 3,86 & 0,722 & & \\
\hline
\end{tabular}

Table 7: Leadership style per Years of Service in Administrative position

\begin{tabular}{|c|c|c|c|c|c|}
\hline Leadership types & $\begin{array}{l}\text { Years of } \\
\text { Service }\end{array}$ & MEAN & SD & Test & P-value \\
\hline \multirow{2}{*}{$\begin{array}{l}\text { Transformational } \\
\text { leadership }\end{array}$} & $<=6$ & 3,93 & 0,232 & \multirow{2}{*}{ Mann-Whitney } & \multirow{2}{*}{0,160} \\
\hline & $7+$ & 4,12 & 0,360 & & \\
\hline \multirow{2}{*}{$\begin{array}{l}\text { Transactional } \\
\text { leadership }\end{array}$} & $<=6$ & 3,74 & 0,314 & \multirow{2}{*}{ Mann-Whitney } & \multirow{2}{*}{0,332} \\
\hline & $7+$ & 3,97 & 0,599 & & \\
\hline \multirow{2}{*}{$\begin{array}{l}\text { Passive to avoid } \\
\text { leadership }\end{array}$} & $<=6$ & 1,52 & 0,559 & \multirow{2}{*}{ Mann-Whitney } & \multirow{2}{*}{0,436} \\
\hline & $7+$ & 1,64 & 0,576 & & \\
\hline \multirow{2}{*}{ Outcome leadership } & $<=6$ & 3,97 & 0,189 & \multirow{2}{*}{ Mann-Whitney } & \multirow{2}{*}{0,796} \\
\hline & $7+$ & 4,04 & 0,642 & & \\
\hline \multirow{2}{*}{ Digital leadership } & $<=6$ & 4,18 & 0,846 & \multirow{2}{*}{ Mann-Whitney } & \multirow{2}{*}{0,099} \\
\hline & $7+$ & 3,78 & 0,742 & & \\
\hline
\end{tabular}


Table 8: Leadership style per Years of Service in Object Direction

\begin{tabular}{|c|c|c|c|c|c|}
\hline Leadership types & Object Direction & MEAN & SD & Test & P-value \\
\hline \multirow{2}{*}{$\begin{array}{c}\text { Transformational } \\
\text { leadership }\end{array}$} & $\begin{array}{l}\text { Humanities and Social } \\
\text { Sciences Direction }\end{array}$ & 4,00 & 0,280 & \multirow{2}{*}{$\begin{array}{l}\text { Mann- } \\
\text { Whitney }\end{array}$} & \multirow{2}{*}{0,856} \\
\hline & $\begin{array}{l}\text { Natural and Applied } \\
\text { Sciences Direction }\end{array}$ & 4,09 & 0,352 & & \\
\hline \multirow{2}{*}{$\begin{array}{l}\text { Transactional } \\
\text { leadership }\end{array}$} & $\begin{array}{c}\text { Humanities and Social } \\
\text { Sciences Direction }\end{array}$ & 3,73 & 0,290 & \multirow{2}{*}{$\begin{array}{l}\text { Mann- } \\
\text { Whitney }\end{array}$} & \multirow{2}{*}{0,389} \\
\hline & $\begin{array}{l}\text { Natural and Applied } \\
\text { Sciences Direction }\end{array}$ & 3,94 & 0,597 & & \\
\hline \multirow{2}{*}{$\begin{array}{l}\text { Passive to avoid } \\
\text { leadership }\end{array}$} & $\begin{array}{c}\text { Humanities and Social } \\
\text { Sciences Direction }\end{array}$ & 1,60 & 0,828 & \multirow{2}{*}{$\begin{array}{l}\text { Mann- } \\
\text { Whitney }\end{array}$} & \multirow{2}{*}{0,389} \\
\hline & $\begin{array}{c}\text { Natural and Applied } \\
\text { Sciences Direction }\end{array}$ & 1,59 & 0,454 & & \\
\hline \multirow{2}{*}{$\begin{array}{l}\text { Outcome } \\
\text { leadership }\end{array}$} & $\begin{array}{l}\text { Humanities and Social } \\
\text { Sciences Direction }\end{array}$ & 3,92 & 0,277 & \multirow{2}{*}{$\begin{array}{l}\text { Mann- } \\
\text { Whitney }\end{array}$} & \multirow{2}{*}{0,696} \\
\hline & $\begin{array}{l}\text { Natural and Applied } \\
\text { Sciences Direction }\end{array}$ & 4,06 & 0,608 & & \\
\hline \multirow{2}{*}{$\begin{array}{l}\text { Digital } \\
\text { leadership }\end{array}$} & $\begin{array}{l}\text { Humanities and Social } \\
\text { Sciences Direction }\end{array}$ & 4,15 & 0,707 & \multirow{2}{*}{$\begin{array}{l}\text { Mann- } \\
\text { Whitney }\end{array}$} & \multirow{2}{*}{0,418} \\
\hline & $\begin{array}{l}\text { Natural and Applied } \\
\text { Sciences Direction }\end{array}$ & 3,93 & 0,716 & & \\
\hline
\end{tabular}

Based on the above tables, leadership types per Age (table 5), leadership types per Years of Service in Higher Education (table 6), leadership style per Years of Service in Administrative (table 7), leadership style per Years of Service in Object Direction (table 8), they do not seem to affect the degree to which the various leadership styles are performed.

\subsection{Leadership outcome}

The possible relationship of different leadership types with leadership outcomes is investigated using the Pearson correlation coefficient.

Table 9: Correlation Outcome leadership vs Leadership style

\begin{tabular}{lccc}
\hline & $\begin{array}{c}\text { Transformational } \\
\text { leadership }\end{array}$ & $\begin{array}{c}\text { Transactional } \\
\text { leadership }\end{array}$ & $\begin{array}{c}\text { Passive to avoid } \\
\text { leadership }\end{array}$ \\
\hline Leadership Outcome & $\mathrm{R}^{1}$ & $\mathrm{R}^{1}$ & $\mathrm{R}^{1}$ \\
\hline
\end{tabular}

${ }^{1}$ Coefficient correlation Pearson

* Correlation is statistically significant at level 0,05

** Correlation is statistically significant at level 0,01

Leadership outcome showed a significant positive and statistically significant correlation with transformational leadership $(\mathrm{R}=0.631)$ and transactional leadership $(R=0.548)$ at $\alpha=0.01$. This means that a great degree of practicing these leadership types coexists with the effectiveness and satisfaction of exercising leadership. On the contrary, the correlation between leadership outcome and 
passive - to avoid leadership is negligible. The emergence of statistically significant correlations lays the groundwork for the application of simple linear regression in order to see if there is a particular dependence of the leadership outcome on each leadership style individually. The multiple regression solution was not preferred due to the strong correlations between the independent variables. In the following regressions, leadership outcome is defined as a dependent variable and each leadership style as an independent variable. The relevant table 10 shows the basic parameters $\beta, R^{2}$ and $p$-value.

Table 10: Outcome leadership according to Leadership style (Simple Linear Regression)

\begin{tabular}{cc|c|c|c}
\hline $\begin{array}{c}\text { Dependent } \\
\text { Variable }\end{array}$ & $\begin{array}{c}\text { Parameters } \\
\text { of Simple } \\
\text { Linear } \\
\text { Regression }\end{array}$ & $\begin{array}{c}\text { Transformational } \\
\text { leadership }\end{array}$ & $\begin{array}{c}\text { Transactional } \\
\text { leadership }\end{array}$ & $\begin{array}{c}\text { Passive to } \\
\text { avoid } \\
\text { leadership }\end{array}$ \\
\hline \multirow{2}{*}{$\begin{array}{c}\text { Outcome } \\
\text { leadership }\end{array}$} & Coefficient $\beta$ & 1,003 & 0,549 & $-0,026$ \\
\cline { 2 - 5 } & $\mathrm{p}$-value & $0,000^{* *}$ & $0,003^{* *}$ & 0,888 \\
\cline { 2 - 5 } & $\mathrm{R}^{2}$ & 0,399 & 0,300 & 0,001 \\
\hline
\end{tabular}

* Influence is statistically significant at level 0,05

** Influence is statistically significant at level 0,01

As it is obvious, transformational leadership has a positive and statistically significant $(p=0.000<0.05)$ impact on leadership outcomes, that is, the greater the application of that leadership style the greater the effectiveness and satisfaction of employees. Indeed, this independent variable interprets a relatively large proportion of the leadership outcome variability $\left(R^{2}=0.399\right)$. Leadership outcome was statistically significantly dependent on transactional leadership $(p=0.003$ $<0.05)$. The more leaders exhibit this leadership style, the greater the effectiveness and satisfaction shown. This independent variable accounts for $30.0 \%$ of the leadership outcome variability $\left(\mathrm{R}^{2}=0.300\right)$. As for passive leadership, this does not seem to have a statistically significant impact on leadership outcomes.

\subsection{Association of digital leadership with leadership types}

The possible relationship of different leadership types with digital leadership is investigated using the Pearson correlation coefficient (table 11).

Table 11: Association of Digital Leadership with Leadership Style

\begin{tabular}{ccccc}
\hline & $\begin{array}{c}\text { Transformational } \\
\text { leadership }\end{array}$ & $\begin{array}{c}\text { Transactional } \\
\text { leadership }\end{array}$ & $\begin{array}{c}\text { Passive to } \\
\text { avoid } \\
\text { leadership }\end{array}$ & $\begin{array}{c}\text { Outcome } \\
\text { leadership }\end{array}$ \\
\hline $\begin{array}{c}\text { Digital } \\
\text { leadership }\end{array}$ & 0,090 & $\mathrm{R}^{1}$ & $\mathrm{R}^{1}$ & $\mathrm{R}^{1}$ \\
\hline
\end{tabular}

${ }^{1}$ Coefficient correlation Pearson

* Association is statistically important at level 0,05 
Digital leadership showed a significant positive and statistically significant correlation with leadership outcome $(r=0.459)$ at $\alpha=0.05$ level. This means that a high degree of effectiveness and satisfaction coexists with a high degree of implementation of digital leadership. The existence of a statistically significant correlation enables us to apply simple linear regression to see if there is a specific dependence on digital leadership for each leadership style. In the following regressions digital leadership is defined as a dependent variable and each leadership style as an independent variable. The relevant table shows the basic parameters $\beta, \mathrm{R}^{2}$ and $\mathrm{p}$-value.

Table 12: Dependence of Digital Leadership on Leadership Style

\begin{tabular}{lc|c|c|c|c}
\hline \multirow{2}{*}{$\begin{array}{c}\text { Dependent } \\
\text { Variable }\end{array}$} & $\begin{array}{c}\text { Parameters } \\
\text { of Simple } \\
\text { Linear } \\
\text { Regression }\end{array}$ & $\begin{array}{c}\text { Transformational } \\
\text { leadership }\end{array}$ & $\begin{array}{c}\text { Transactional } \\
\text { leadership }\end{array}$ & $\begin{array}{c}\text { Passive to } \\
\text { avoid } \\
\text { leadership }\end{array}$ & $\begin{array}{c}\text { Outcome } \\
\text { leadership }\end{array}$ \\
\hline \multirow{2}{*}{$\begin{array}{c}\text { Digital } \\
\text { leadership }\end{array}$} & $\begin{array}{c}\text { Coefficient } \\
\beta\end{array}$ & 0,217 & $-0,104$ & 0,121 & 0,694 \\
\cline { 2 - 6 } & $\mathrm{p}$-value & 0,647 & 0,729 & 0,661 & $0,014^{*}$ \\
\cline { 2 - 6 } & $\mathrm{R}^{2}$ & 0,008 & 0,005 & 0,008 & 0,211 \\
\hline
\end{tabular}

${ }^{*}$ Influence is statistically significant at a level 0,05

According to Table 12, leadership outcomes had a positive and statistically significant $(p=0.014<0.05)$ digital leadership, that is, the greater the effectiveness and satisfaction of practicing leadership, the greater the degree of digital leadership. Indeed, this independent variable interprets a significant percentage of digital leadership volatility $\left(\mathrm{R}^{2}=0.211\right)$. Regarding transformational, transactional and passive leadership, these do not seem to have a statistically significant impact on the degree of digital leadership.

\subsection{Required digital skills}

Subsequently, the research participants were asked to list the digital characteristics that they could exploit and consider it more necessary for a leader. Respondents were able to state more than one choice.

Table 13: Digital skills for a leader

\begin{tabular}{|c|c|c|c|}
\hline & & $\begin{array}{c}\Sigma Y X N O T H T A \\
(\mathrm{~N})\end{array}$ & 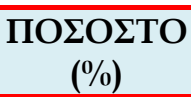 \\
\hline \multirow{9}{*}{$\begin{array}{c}\text { Digital } \\
\text { Characteristics }\end{array}$} & Social Media & 17 & 60,7 \\
\hline & Cloud Computing & 17 & 60,7 \\
\hline & Mobile App & 15 & 53,6 \\
\hline & Web Development and Tools & 12 & 42,9 \\
\hline & Big Data & 10 & 35,7 \\
\hline & ERP Systems & 8 & 28,6 \\
\hline & Security Skills & 5 & 17,9 \\
\hline & Digital Architecture & 2 & 7,1 \\
\hline & Complex Business Systems & 1 & 3,6 \\
\hline
\end{tabular}


The widespread digital skills of Social Media, Cloud Computing and Mobile App are also the ones that received the majority of responses $(60.7 \%, 60.7 \%$ and $53.6 \%$ respectively). However, a significant proportion of respondents can take advantage of Web Development and Tools (42.9\%) and Big Data applications $(35.7 \%)$. Digital architectures and Complex Business Systems are exploited by few respondents.

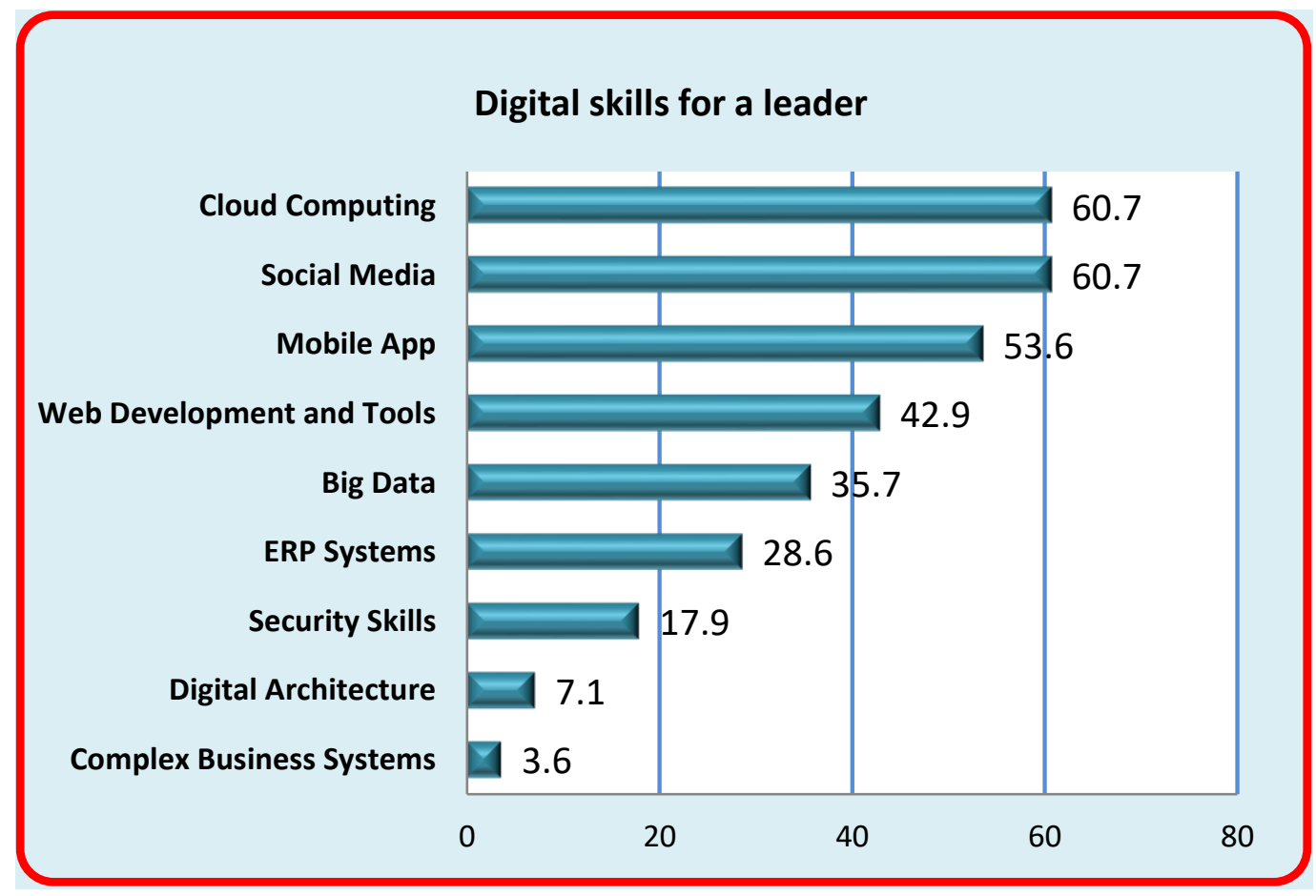

Figure 3: Digital skills that can be considered as necessary for a leader

To determine if demographic characteristics had a statistically significant effect on the declared digital skills, an $\mathrm{X}^{2}$ test was performed. The table 14 shows only the statistically significant differences.

Table 14: Mobile App per Demographic Characteristics

\begin{tabular}{|c|c|c|c|c|}
\hline $\begin{array}{l}\text { Demographic } \\
\text { Characteristics }\end{array}$ & & $\%$ & Test & P-value \\
\hline \multirow{3}{*}{ AGE } & $41-50$ & 100,0 & \multirow{3}{*}{$X^{2}$} & \multirow{3}{*}{$0,002^{* *}$} \\
\hline & $51-60$ & 72,7 & & \\
\hline & $>60$ & 16,7 & & \\
\hline \multirow{2}{*}{$\begin{array}{l}\text { YEARS OF SERVICE IN } \\
\text { HIGHER EDUCATION }\end{array}$} & $<20$ & 100,0 & \multirow{2}{*}{$X^{2}$} & \multirow{2}{*}{$0,004^{* *}$} \\
\hline & $>20$ & 38,1 & & \\
\hline \multirow{2}{*}{$\begin{array}{l}\text { YEARS OF SERVICE IN } \\
\text { ADMINISTRATIVE } \\
\text { POSITION }\end{array}$} & $<=6$ & 90,0 & \multirow{2}{*}{$X^{2}$} & \multirow{2}{*}{$0,004^{* *}$} \\
\hline & $7+$ & 33,3 & & \\
\hline
\end{tabular}


Based on Table 14, we find that the higher the age of respondents and the longer their years of service in higher education and administration, the less likely they are to exploit and consider Mobile App significant ( $p<0.05$ ). It is also noted that ERP Systems were only reported by Natural and Applied Sciences Direction participants, Digital Architectures only by Natural and Applied Sciences Direction women over 60, and Security Skills by male only. Alternatively, the number of digital skills stated by research participants that can be exploited and considered important for a leader was examined.

Table 15: Number of digital skills

\begin{tabular}{lccccc}
\hline & N & Min & Max & MEAN & SD \\
\hline Number of digital skills & 28 & 1 & 6 & 3,11 & 1,524 \\
\hline
\end{tabular}

On average, respondents reported about 3 of the 9 existing skills. There were participants who stated only one (1) but also participants who stated up to six (6). No respondent stated more than 6 skills.

In order to determine if demographic characteristics had a statistically significant effect on the number of declared digital skills, non-parametric Mann-Whitney statistical tests were performed.

Table 16: Number of digital skills per demographic feature

\begin{tabular}{|c|c|c|c|c|c|}
\hline & Numb & f Skills & SD & Test & $\begin{array}{c}\mathrm{P}- \\
\text { value }\end{array}$ \\
\hline \multirow{2}{*}{ SEX } & Male & 3,05 & 1,532 & \multirow{2}{*}{$\begin{array}{l}\text { Mann- } \\
\text { Whitney }\end{array}$} & \multirow{2}{*}{0,756} \\
\hline & Female & 3,29 & 1,604 & & \\
\hline \multirow{3}{*}{ AGE } & $41-50$ & 3,20 & 1,643 & \multirow{3}{*}{$\begin{array}{l}\text { Mann- } \\
\text { Whitney }\end{array}$} & \multirow{3}{*}{0,993} \\
\hline & $51-60$ & 3,09 & 1,640 & & \\
\hline & $>60$ & 3,08 & 1,505 & & \\
\hline \multirow{2}{*}{$\begin{array}{c}\text { YEARS OF } \\
\text { SERVICE IN } \\
\text { HIGHER } \\
\text { EDUCATION }\end{array}$} & $<20$ & 3,14 & 1,345 & \multirow{2}{*}{$\begin{array}{c}\text { Mann- } \\
\text { Whitney }\end{array}$} & \multirow[b]{2}{*}{0,917} \\
\hline & $>20$ & 3,10 & 1,609 & & \\
\hline \multirow{2}{*}{$\begin{array}{c}\text { YEARS OF } \\
\text { SERVICE IN } \\
\text { ADMINISTRATIVE } \\
\text { POSITION }\end{array}$} & $<=6$ & 3,40 & 1,578 & \multirow{2}{*}{$\begin{array}{l}\text { Mann- } \\
\text { Whitney }\end{array}$} & \multirow{2}{*}{0,464} \\
\hline & $7+$ & 2,94 & 1,514 & & \\
\hline \multirow{2}{*}{ SUBJECT FIELD } & $\begin{array}{l}\text { Humanities and Social } \\
\text { Sciences Direction }\end{array}$ & 3,13 & 1,642 & \multirow{2}{*}{$\begin{array}{c}\text { Mann- } \\
\text { Whitney }\end{array}$} & \multirow{2}{*}{0,979} \\
\hline & $\begin{array}{l}\text { Natural and Applied } \\
\text { Sciences Direction }\end{array}$ & 3,16 & 1,537 & & \\
\hline
\end{tabular}

Based on Table 16, it appears that demographic characteristics did not affect the number of digital skills reported by respondents. 
Subsequently, the relationship of different leadership types with the number of declared digital skills was investigated.

Table 17: Number of Digital Skills associated with Leadership Style

\begin{tabular}{lccccc}
\hline & $\begin{array}{c}\text { Transformational } \\
\text { leadership }\end{array}$ & $\begin{array}{c}\text { Transactional } \\
\text { leadership }\end{array}$ & $\begin{array}{c}\text { Passive to } \\
\text { avoid } \\
\text { leadership }\end{array}$ & $\begin{array}{c}\text { Outcome } \\
\text { leadership }\end{array}$ & $\begin{array}{c}\text { Digital } \\
\text { leadership }\end{array}$ \\
\hline $\mathrm{R}^{1}$ & $\mathrm{R}^{1}$ & $\mathrm{R}^{1}$ & $\mathrm{R}^{1}$ & $\mathrm{R}^{1}$ \\
\hline $\begin{array}{l}\text { Number of } \\
\text { Digital Skills }\end{array}$ & $-0,296$ & $-0,398^{*}$ & $-0,009$ & $-0,162$ & 0,352 \\
\hline
\end{tabular}

${ }^{1}$ Coefficient correlation Pearson

*Association is significant in statistic level $p<0,05$

Based on Table 17, there was a statistically significant negative correlation between the number of declared digital skills with transactional leadership ( $\mathrm{R}=$ 0.398). That is, a high degree of transactional leadership practice coexists with a low number of declared digital skills.

Finally, the variable of the number of digital skills was recoded to show the percentages of respondents who stated few or many skills.

Table 18: Number of digital skills useful for a leader

\begin{tabular}{cccc}
\hline & & $\begin{array}{c}\Sigma \text { YXNOTHTA } \\
(\mathbf{N})\end{array}$ & $\begin{array}{c}\Pi 0 \Sigma \mathrm{\Sigma} \Sigma \mathrm{TTO} \\
(\%)\end{array}$ \\
\hline $\begin{array}{c}\text { Number of Digital } \\
\text { Skills }\end{array}$ & Low (1-3) & 17 & 60,7 \\
\hline
\end{tabular}

$3 / 5$ of the respondents stated that a small number of digital skills can be exploited, and they think they are more needed for a leader.

Table 19: Levels of Digital Leadership Skills

\begin{tabular}{|c|c|c|c|c|c|}
\hline & & $\begin{array}{c}\text { Digital } \\
\text { Leadership } \\
\text { Levels } \\
\end{array}$ & SD & Test & P-value \\
\hline \multirow{2}{*}{$\begin{array}{c}\text { Number of } \\
\text { Digital Skills }\end{array}$} & $\operatorname{Low}(1-4)$ & 3,72 & 0,837 & \multirow{2}{*}{$\begin{array}{l}\text { Mann- } \\
\text { Whitney }\end{array}$} & \multirow{2}{*}{0,091} \\
\hline & Intermediate (4-6) & 4,24 & 0,619 & & \\
\hline
\end{tabular}

Respondents with an average number of declared digital skills show a higher degree of digital leadership (Mean $=4.24$ ) than those who reported a low number $($ Mean $=3.72)$. However, this difference is not statistically significant $(p=0.091>$ $0.05)$. 


\section{Discussion}

In conclusion, the results of the present study identified gender as a key factor in practicing any leadership style. Specifically, male participants have Transformational Leadership, Transactional Leadership, and Digital Leadership to a statistically significantly higher extent than female participants. Also, male participants appeared to be more satisfied with the outcome of the leadership they followed. Leadership outcome has a significant positive and statistically significant relationship with transformational leadership as well as transactional leadership. This means that a great degree of practicing these leadership types coexists with the effectiveness and satisfaction of exercising leadership. Finally, digital leadership positively correlates with leadership outcomes. This means that effectiveness and satisfaction with leadership practice coexist with the high degree of implementation of digital leadership. Leadership outcomes have a positive impact on Digital Leadership, as the greater the effectiveness and satisfaction of practicing leadership, the greater the degree of Digital Leadership. Complementary to the MLQ tool used as a data collection tool in the present research work is a tool that has been used incessantly over the last 28 years to evaluate and categorize educational organization leaders regarding their effectiveness index (Bass $\mathcal{E}$ Avolio, 2004). The results of the present study are in line with previous studies conducted in a variety of educational settings and report, inter alia, that transformational leadership components are positively correlated with the effectiveness and satisfaction of their existing leaders.

Therefore, and in the light of the foregoing, the consolidation of educational leadership in structures, mindsets and situations of the past without incorporating the characteristics of digital leadership does not promote higher education and the work of the human resources that lead it. Educators need to be vigilant, striving, up to date on new technologies and capabilities of digital tools, participating in quality training / retraining programs to gradually integrate them into educational leadership. Similarly, the central leadership mechanism requires to give motivation, a substantial reward for excellent professors, and the launch of meaningful assessment processes if the current situation is really a priority.

\section{Conclusion}

In summary, we find that the issue of digital leadership in educational settings is particularly interesting and essential because its proper practice has beneficial effects on all aspects of the functioning of an educational organization. The present research could potentially provide a further reason for the scientific community to engage other researchers in Greece with the field of integrating digital culture into higher education educational leadership issues.

\section{Limitations}

The study has some limitations. The sample of the study is quite small due to the fact that the Senate of the Higher Education Institutions consists of a limited number of members. In addition, there was a considerable difficulty in direct contact with the members of the Senate in order to participate in the research, due to the heavy workload and obligations of the Institutions. In this phase, the 
researchers' direct communication with the members of the Senate was activated, via personal interviews, in order to complete the present research study.

\section{Recommendations}

The study highlighted the specific characteristics of the leadership style of the members of the Senate of the University of Patras. Due to the limitation of the small sample, the generalization of conclusions is a matter for further investigation. In the next period, samples are expected to be evaluated by other Universities in order to collect extended sample that could yield statistically significant results, which may contribute to the generalization of the conclusions regarding the thematic field of digital leadership in Higher Education.

\section{Acknowledgments}

Special Thanks to the Members of the Senate of the University of Patras for the contribution in the implementation of the current research project.

\section{References}

Antonopoulou, H., Halkiopoulos, C., Barlou, O., \& Beligiannis, G. (2019). Transition from Educational Leadership to e-Leadership: A Data Analysis Report from TEI of Western Greece. International Journal of Learning, Teaching and Educational Research 18(9), 238-255. https:// doi.org/10.26803/ijlter.18.9.13

Arnold, D., \& Sangrà, A. (2018): Dawn or dusk of the 5th age of research in educational technology? A literature review on (e-)leadership for technology-enhanced learning in higher education (2013-2017). International Journal of Educational Technology in Higher Education, 15. https:/ / doi.org/10.1186/s41239-018-0104-3

Avolio, B. J., \& Bass B. M. (1988). Charisma and beyond: Research findings on transformational and transactional leadership. In Hunt, G. H., Baligo, B. R., Dachler, H. P. and Schiersheim (eds), Emerging Leadership Vistas. Boston, MA: Lexington.

Avolio, B. J., \& Bass, B. M. (2004). Multifactor Leadership Questionnaire. Sampler Set. Manual, Forms and Scoring Key. Mind Garden, Inc.

Avolio, B. J., Bass, B. M., \& Jung, D. I. (1999). Re-examining the components of transformational and transactional leadership using the Multifactor Leadership Questionnaire. Journal of Occupational and Organizational Psychology, 72(4), 441-462. https://doi.org/10.1348/096317999166789

Balvant, P. (2016). Transformational Instructor Leadership in higher education teaching: A Metaanalytic Review and research review and Research Agenda. Journal of Leadership Studies, 9(4), 20-42. https://doi.org/10.1002/jls.21423

Barnett, A. (2003). The impact of transformational leadership style of the school principal on school learning environments and selected teacher outcomes: A preliminary report. Paper presented at Nzare Aare, Auckland, New Zealand.

Bass, B. M. (1985). Leadership and Performance Beyond Expectations. New York: Free Press.

Bass, B. M. (1997). Does the transactional-transformational leadership paradigm transcend organizational and national boundaries? American Psychologist, 52(2), 130-139.

Bass, B. M. (1998). Transformational leadership: Industry, military and educational impact. Mahwah, NJ: Lawrence \& Erlbaum.

Bass, B. M., \& Avolio, B. J. (1994). Transformational leadership and organizational culture. International Journal of Public Administration, 17, 541-555. 
Bass, B. M., \& Bass, R. (2008). The Bass handbook of leadership, theory, research and managerial applications (4th ed.). New York: Free Press.

Bennis, W. G. (1990). A force for Change: How leadership differs from management. US/UK: Macmillan.

Bolden, R., Petrov, G., \& Gosling, J. (2008). Developing collective leadership in higher education. In H. Goreham (ed.), Research and Development Series. London: Leadership Foundation for Higher Education.

Bryant, S. E. (2003). The role of transformational and transactional leadership in creating, sharing and exploiting organizational knowledge. Journal of Leadership and Organizational Studies, 9(4), 32-44.

Carless, S., Wearing, A., \& Mann, L. (2000). A short measure of transformational leadership. Journal of Business and Psychology, 14(3), 389.

Cortellazzo, L., Bruni, E., \& Zampieri R. (2019) The Role of Leadership in a Digitalized World: A Review. Frontiers in Psychology, 10, 1938.

Cuban, L. (1988). The Managerial Imperative and the Practice of Leadership in Schools. Albany, NY: State University of New York Press.

European Commission's Directorate General Enterprise and Industry. (2012). eLeadership: Skills for Competitiveness and Innovation.

Fullan, M. (2002). Principals as leaders in a culture of change. Educational leadership. Retrieved from http://www.michaelfullan.ca/Articles_02/03_02.htm

Gellis, Z. D. (2001). Social work perceptions of transformational and transactional leadership in health care. Social Work Research, 25(1), 17-25.

Howell, J., \& Avolio B. (1993). Transformational leadership, transactional leadership, locus of control and support. Journal of Applied Psychology, 78(6), 891-893.

Howell, J. M., \& Hall-Merenda, K. E. (1999). The ties that bind: The impact of leader member exchange, transformational and transactional leadership and distance on predicting follower performance. Journal of Applied Psychology, 84(5), 680-694.

Jenkins, D. M., \& Andenoro, A. C. (2016). Developing Critical Thinking Through Leadership Education. New Directions for Higher Education, 174, 57-67. https://doi.org/10.1002/he.20189

Judge, T. A., \& Piccolo, R. F. (2004). Transformational and transactional leadership: A meta-analytic test of their relative validity. Journal of Applied Psychology, 89(5), 755768.

Lighton, J. R. B. (2018). Acquiring Useful Tools and Skills. In Measuring Metabolic Rates : A Manual for Scientists (pp. 232-238). Oxford Scholarship Online. https://doi.org/10.1093/oso/9780198830399.003.0020

Lowe, K. B., Kroeck, K. G., \& Sivasubramaniam, N. (1996). Effectiveness correlates of transformation and transactional leadership: A meta-analytic review of the MLQ literature. The Leadership Quarterly, 7, 385-425.

Lussier, R. N., \& Achua, C. F. (2004). Leadership: theory, application, skill development (2nd ed.). Eagan, MN: Thomson-West.

Northouse, P. G. (2016). Leadership. Theory and practice (7nd ed). Los Angeles: SAGE.

Waldman, D. A., Atwater, L., \& Bass, B. M. (1992). Transformational leadership and innovative performance in a $\mathrm{R} \& \mathrm{D}$ laboratory (final report). Bethlehem, PA: Lehigh University, Center for Innovation Management Studies. Administration, 40(4), 368-384. 


\section{Leadership in Higher Education}

This questionnaire (Multi-leadership Questionnaire (MLQ) from Bass and Avolio (1995)) is anonymous and is addressed to Department Presidents / Deans / Vice-Deans of Academic Foundations.

The answers are completely confidential and the resulting information will only be used for research purposes.

It does not take more than 10 minutes to complete.

Thank you in advance for your cooperation.

* Required

\section{Demographics:}

1. Gender: *

Mark only one oval.

$\bigcirc$ Male

$\bigcirc$ Female

2. Age group: *

Mark only one oval.

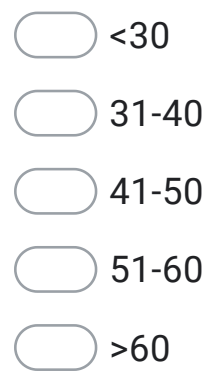


3. Years of Service in Higher Education: *

Mark only one oval.

$0-5$

6-10

11-20

$>20$

4. Years of Service in Management Position: *

Mark only one oval.

0-3

4-6

$7-9$

$>>9$

5. Your Academic Field belongs: *

Mark only one oval.

Theoretical Direction

Positive Direction

Other:

Leadership

Questionnaire
This questionnaire is designed to help you describe your leadership style as you perceive it. Please answer all items on the questionnaire by circling the appropriate response on the rating scale from 0 to 4 the format is given below.

To what extent do you exhibit the following behavior:

The word "other" means Colleagues of the Academic Foundation 
6. 1. I provide others with assistance in exchange for their efforts *

Mark only one oval.

Not at all

Once in a while

$\Longrightarrow$ sometimes

fairly often

$\longrightarrow$ frequently if not always

7. 2. I re-examine critical assumptions to questions whether they are appropriate * Mark only one oval.

Not at all

Once in a while

$\longrightarrow$ sometimes

$\longrightarrow$ fairly often

$\Longrightarrow$ frequently if not always

8. 3. I fail to interfere until problems become serious *

Mark only one oval.

Not at all

Once in a while

$\longrightarrow$ sometimes

$\longrightarrow$ fairly often

$\Longrightarrow$ frequently if not always 
9. 4. I focus attention on irregularities, mistakes, exceptions and deviations * Mark only one oval.

Not at all

Once in a while

sometimes

fairly often

frequently if not always

10. 5. I avoid getting involved when important issues arise * Mark only one oval.

Not at all

Once in a while

sometimes

$\longrightarrow$ fairly often

frequently if not always

11. 6. I talk about my most important values and beliefs * Mark only one oval.

Not at all

Once in a while

sometimes

fairly often

frequently if not always 
12. 7. I am absent when needed *

Mark only one oval.

Not at all

Once in a while

$\longrightarrow$ sometimes

$\longrightarrow$ fairly often

frequently if not always

13. 8. I seek differing perspectives when solving problems * Mark only one oval.

Not at all

Once in a while

$\longrightarrow$ sometimes

$\longrightarrow$ fairly often

$\longrightarrow$ frequently if not always

14. 9. I talk optimistically about the future *

Mark only one oval.

Not at all

Once in a while

sometimes

$\longrightarrow$ fairly often

$\longrightarrow$ frequently if not always 
15. 10. I instill pride in others for being associated with me * Mark only one oval.
Not at all
Once in a while
sometimes
$\Longrightarrow$ fairly often
frequently if not always

16. 11. I discuss in specific terms who is responsible for achieving performance targets *

Mark only one oval.

Not at all

Once in a while

$\longrightarrow$ sometimes

$\longrightarrow$ fairly often

frequently if not always

17. 12. I wait for things to go wrong before taken action * Mark only one oval.
Not at all
Once in a while
sometimes
fairly often
frequently if not always 
18. 13. I talk enthusiastically about what needs to be accomplished * Mark only one oval.
Not at all
Once in a while
$\Longrightarrow$ sometimes
$\longrightarrow$ fairly often
frequently if not always

19. 14. I specify the importance of having a strong sense of purpose * Mark only one oval.
Not at all
Once in a while
$\longrightarrow$ sometimes
$\longrightarrow$ fairly often
frequently if not always

20. 15. I spend time teaching and coaching * Mark only one oval.
Not at all
Once in a while
$\Longrightarrow$ sometimes
$\longrightarrow$ fairly often
frequently if not always 
21. 16. I make clear what one can expect to receive when performance goals are achieved *

Mark only one oval.

Not at all

Once in a while

sometimes

$\Longrightarrow$ fairly often

$\longrightarrow$ frequently if not always

22. 17. I show that I am a firm believer in "If it isn't broke, don't fix it" *

Mark only one oval.

Not at all

Once in a while

$\longrightarrow$ sometimes

$\longrightarrow$ fairly often

frequently if not always

23. 18. I go beyond self-interest for the good of the group * Mark only one oval.

Not at all

Once in a while

sometimes

$\longrightarrow$ fairly often

frequently if not always 
24. 19. I treat others as individuals rather than just as a member of a group * Mark only one oval.
Not at all
Once in a while
sometimes
$\longrightarrow$ fairly often
frequently if not always

25. 20. I demonstrate that problems must become chronic before I take action * Mark only one oval.
Not at all
Once in a while
$\longrightarrow$ sometimes
$\Longrightarrow$ fairly often
frequently if not always

26. 21. I act in ways that build others' respect for me * Mark only one oval.
Not at all
$\Longrightarrow$ Once in a while
$\Longrightarrow$ sometimes
$\longrightarrow$ fairly often
frequently if not always 
27. 22. I concentrate my full intention on dealing with mistakes, complaints, and failures *

Mark only one oval.

Not at all

Once in a while

$\longrightarrow$ sometimes

$\longrightarrow$ fairly often

$\Longrightarrow$ frequently if not always

28. 23. I consider the moral and ethical consequences of decisions * Mark only one oval.

Not at all

Once in a while

$\longrightarrow$ sometimes

$\longrightarrow$ fairly often

frequently if not always

29. 24. I keep tracks of all mistakes *

Mark only one oval.

$\longrightarrow$ Not at all

Once in a while

sometimes

fairly often

$\longrightarrow$ frequently if not always 
30. 25. I display a sense of power and confidence *

Mark only one oval.

Not at all

Once in a while

$\Longrightarrow$ sometimes

$\longrightarrow$ fairly often

frequently if not always

31. 26. I articulate a compelling version of the future * Mark only one oval.

Not at all

Once in a while

$\longrightarrow$ sometimes

$\Longrightarrow$ fairly often

frequently if not always

32. 27. I direct my attention toward failures to meet standards * Mark only one oval.

Not at all

Once in a while

$\longrightarrow$ sometimes

$\longrightarrow$ fairly often

frequently if not always 
33. 28. I avoid making decisions *

Mark only one oval.

Not at all

Once in a while

$\Longrightarrow$ sometimes

$\longrightarrow$ fairly often

frequently if not always

34. 29. I consider an individual as having different needs, abilities, and aspirations from others *

Mark only one oval.

Not at all

Once in a while

sometimes

$\longrightarrow$ fairly often

frequently if not always

35. 30. I get others to look at problems from many different angles * Mark only one oval.

Not at all

Once in a while

$\Longrightarrow$ sometimes

$\longrightarrow$ fairly often

frequently if not always 
36. 31. I help others to develop their strengths *

Mark only one oval.

Not at all

Once in a while

$\Longrightarrow$ sometimes

$\longrightarrow$ fairly often

frequently if not always

37. 32. I suggest new ways of looking at how to complete assignments *

Mark only one oval.

Not at all

$\Longrightarrow$ Once in a while

$\longrightarrow$ sometimes

$\longrightarrow$ fairly often

frequently if not always

38. 33. I delay responding to urgent questions *

Mark only one oval.

Not at all

$\Longrightarrow$ Once in a while

$\longrightarrow$ sometimes

fairly often

frequently if not always 
39. 34. I emphasize the importance of having a collective sense of mission * Mark only one oval.
Not at all
Once in a while
sometimes
$\longrightarrow$ fairly often
frequently if not always

40. 35. I express satisfaction when others meet expectations * Mark only one oval.
Not at all
Once in a while
$\longrightarrow$ sometimes
$\longrightarrow$ fairly often
$\Longrightarrow$ frequently if not always

41. 36. I express confidence that goals will be achieved * Mark only one oval.
Not at all
Once in a while
$\longrightarrow$ sometimes
$\longrightarrow$ fairly often
$\Longrightarrow$ frequently if not always 
42. 37. I am effective in meeting others' job-related needs *

Mark only one oval.

Not at all

Once in a while

$\Longrightarrow$ sometimes

$\longrightarrow$ fairly often

frequently if not always

43. 38. I use methods of leadership that are satisfying *

Mark only one oval.

Not at all

$\Longrightarrow$ Once in a while

$\longrightarrow$ sometimes

$\longrightarrow$ fairly often

frequently if not always

44. 39. I get others to do more than they expected to do * Mark only one oval.

Not at all

$\Longrightarrow$ Once in a while

sometimes

fairly often

frequently if not always 
45. 40. I am effective in representing others to higher authority *

Mark only one oval.

Not at all

Once in a while

sometimes

fairly often

frequently if not always

46. 41. I work with others in a satisfactory way *

Mark only one oval.

Not at all

Once in a while

$\bigcirc$ sometimes

$\longrightarrow$ fairly often

frequently if not always

47. 42. I heighten others' desire to succeed *

Mark only one oval.

Not at all

Once in a while

$\longrightarrow$ sometimes

$\Longrightarrow$ fairly often

frequently if not always 
48. 43. I am effective in meeting organizational requirements *

Mark only one oval.

Not at all

Once in a while

sometimes

$\longrightarrow$ fairly often

frequently if not always

49. 44. I increase others' willingness to try harder *

Mark only one oval.

Not at all

$\Longrightarrow$ Once in a while

$\longrightarrow$ sometimes

$\longrightarrow$ fairly often

frequently if not always

50. 45. I lead a group that is effective *

Mark only one oval.

Not at all

$\Longrightarrow$ Once in a while

sometimes

$\Longrightarrow$ fairly often

frequently if not always 
51. 46. I can take advantage of the opportunities offered by ICT, especially the Internet *

Mark only one oval.

Not at all

Once in a while

sometimes

fairly often

$\bigcirc$ frequently if not always

52. 47. I can ensure more efficient performance of different types of digital organization (ERP, e-Protocol, CRM) *

Mark only one oval.

Not at all

Once in a while

sometimes

fairly often

frequently if not always

53. 48. I can identify, research and exploit opportunities for new ways of conducting educational processes (eg e-learning, video conferences, webinars) *

Mark only one oval.

Not at all

Once in a while

sometimes

fairly often

frequently if not always 
54. 49. I can create research-educational partnerships with corresponding structures abroad, taking advantage of the opportunities provided by the European Union *

Mark only one oval.

Not at all

Once in a while

sometimes

fairly often

frequently if not always

55. 50. I can manage innovative ideas and inventions (eg patents) by leveraging ICT developments *

Mark only one oval.

Not at all

Once in a while

sometimes

fairly often

frequently if not always 
56. 51. Which of the following digital skills can you take advantage of and consider them essential for a Leader: *

Check all that apply.

Big Data

$\square$ Cloud Computing

$\square$ Mobile App

$\square$ Complex Business Systems

$\square$ Web Development and Tools

$\square$ Digital Architecture

$\square$ Security Skills

$\square$ ERP Systems

$\square$ Social Media 